\title{
Pemodelan Spasial Genangan Banjir Akibat Gelombang Pasang di Wilayah Pesisir Kota Mataram
}

\author{
Mohamad Rio Rahmanto dan Cahyono Susetyo \\ Perencanaan Wilayah dan Kota, Fakultas Arsitektur Desain dan Perencanaan \\ Institut Teknologi Sepuluh Nopember (ITS) \\ e-mail: cahyono_s@urplan.its.ac.id
}

\begin{abstract}
Abstrak-Dampak kenaikan muka air laut di Kota Mataram menyebabkan 6 (enam) Kelurahan di 2 (dua) Kecamatan terdampak banjir tiap tahunnya. Untuk mencegah kerusakan yang lebih parah, solusi yang dapat dilakukan adalah membuat pemodelan wilayah terdampak banjir sebagai acuan dalam perencanaan pembangunan kedepannya. Pada bulan Januari 2017, gelombang pasang merendam 1.161 rumah warga di tujuh kelurahan mencakup dua kecamatan, yakni Ampenan dan Sekarbela. Di Ampenan ada empat kelurahan yang terkena dampaknya, yaitu Kelurahan Bintaro, Ampenan Tengah, Banjar, dan Ampenan Selatan. Kecamatan Sekarbela: Kelurahan Tanjung Karang Permai, Tanjung Karang, dan Jempong Baru. Dari hasil model dapat diketahui bahwa : (1) Aspek yang paling berpengaruh dalam menentukan seberapa luas banjir ialah ketelitian dari data Digital Elevation Model. (2) Luasan wilayah banjir tahun 2016 seluas 102,866 ha, tahun 2066 seluas 145,7638 ha, dan tahun 2116 seluas 187,8490 ha. Wilayah yang tergenang sebagian besar berupa permukiman dan kawasan pertanian.
\end{abstract}

Kata Kunci-Banjir, Kenaikan Muka Air Laut, Raster Calculator, Digital Elevation Model.

\section{PENDAHULUAN}

$\mathrm{P}$ EMANASAN global ialah meningkatnya temperatur suhu rata-rata di atmosfer, laut dan daratan di bumi. Peningkatan yang cukup drastis ini disebabkan oleh pembakaran bahan bakar fosil, seperti batu bara, minyak bumi dan gas alam. Hasil dari pembakaran bahan bakar fosil melepaskan karbon dioksida dan gas-gas lainnya yang dikenal sebagai gas rumah kaca ke atmosfer bumi [1]

Akibat dari meningkatnya konsentrasi $\mathrm{CO} 2$, muncul beberapa dampak seperti yang dilansir dari stasiun meteorologi di Kutub Utara telah menunjukan adanya peningkatan temperatur suhu tahunan hingga $1{ }^{\circ} \mathrm{C}$ dalam satu generasi terakhir. Dampak buruk dari meningkatnya suhu tersebut adalah melelehnya gletser (melting of glaciers) dan tenggelamnya bongkahan es di wilayah Alaska dan Siberia, sehingga dapat menyebabkan naiknya permukaan laut hingga mampu menenggelamkan pulau-pulau dan menimbulkan banjir besar di berbagai wilayah dataran rendah [2]

Sejak 1861 hingga 2005 telah terjadi peningkatan suhu di bumi $0,6-0,7^{\circ} \mathrm{C}$, sementara itu diprediksi pada tahun 2100 suhu di bumi meningkat $1,4-5,8^{\circ} \mathrm{C}$ [3] Jika terjadi peningkatan temperatur bumi sampai $2^{\circ} \mathrm{C}$, maka akan banyak terjadi gelombang pasang di daerah pantai setiap tahunnya dan mempengaruhi kehidupan jutaan orang yang tinggal di pantai. Pulau pulau kecil dan dataran rendah dari garis pantai menjadi sangat rentan oleh gelombang pasang terutama di benua Afrika dan Asia [1]. Hasil proyeksi kenaikan muka air laut untuk wilayah Indonesia, yang menunjukkan wilayah Indonesia mengalami kehilangan daratan-daratan akibat kenaikan muka air laut. Jika diambil hasil proyeksi untuk tahun 2010, 2050 dan 2100 dengan daratan yang hilang secara berturut-turut seluas $7408 \mathrm{~km} 2,30120 \mathrm{~km} 2,90260 \mathrm{~km} 2$. [4]

Selain itu, jika suhu bumi terus meningkat El Nino akan lebih sering terjadi di Indonesia. El Nino ialah fenomena di lautan Pasifik dimana lautan yang hangat mengalir di pantai barat Ekuador dan Peru yang mengakibatkan perubahan iklim yang sangat genting dan biasanya terjadi pada bulan Desember. Dampaknya jika temperatur di permukaan air meningkat, maka badai tropis akan lebih sering terjadi karena air akan lebih cepat menguap dan angin bertiup lebih kencang seperti topan badai [1]

Wilayah pesisir yang merupakan batas antara darat dan laut menjadikannya sebagai daerah yang cukup berpotensi, terbukti sebagian besar masyarakat Indonesia tersebar didalamnya. Secara sosial, wilayah pesisir dihuni tidak kurang dari 110 juta jiwa atau 60\% dari penduduk Indonesia yang bertempat tinggal dalam radius $50 \mathrm{~km}$ dari garis pantai. [5] Secara geografis, sisi barat Kota Mataram berbatasan langsung dengan Selat Lombok. Kota Mataram memiliki garis pantai dengan panjang $9 \mathrm{Km}$ (kilometer) membentang dari utara hingga selatan. Dalam RTRW Kota Mataram Tahun 2011-2031, wilayah yang berbatasan langsung dengan pesisir ialah Kecamatan Ampenan dan Kecamatan Serkarbela. Gelombang pasang yang terjadi di wilayah pesisir Kota Mataram terjadi setiap tahunnya pada musim angin barat atau sekitar bulan Juni hingga Desember.

Di 2 (dua) Kecamatan tersebut terdapat 15 (lima belas) Kelurahan, 6 (enam) Kelurahan diantaranya (Bintaro, Ampenan Tengah, Ampenan Selatan, Tanjung Karang Permai, Tanjung Karang, dan Jempong Baru) terkena banjir akibat gelombang pasang. Selama bulan Mei 2016 dampak dari gelombang pasang di 6 (enam) Kelurahan tersebut mengakibatkan 3 (tiga) rumah rusak berat, 2 (dua) perahu milik nelayan hancur, 42 (empat puluh dua) kepala keluarga mengungsi, serta ratusan rumah terendam. [6] Menurut aturan sempadan pantai sekitar 100 meter, tetapi kondisi saat ini masih banyak rumah penduduk yang dibangun bahkan kurang dari 50 meter dari sempadan pantai [7] 
Bukan tidak mungkin, sisi barat Kota Mataram yaitu Kecamatan Ampenan dan Kecamatan Sekarbela di 50 tahun mendatang terendam banjir gelombang pasang akibat perubahan iklim disertai peningkatan ketinggian permukaan air laut yang merupakan efek dari pemanasan global. Untuk itu, perlu dilakukan sebuah pemodelan luasan wilayah yang terdampak banjir akibat gelombang pasang guna mengurangi korban jiwa dan kerugian secara materi di masa mendatang.

\section{METODE PENELITIAN}

\section{A. Metode Pengumpulan Data}

Data yang digunakan pada penelitian ini adalah data spot height berupa data titik kontrol suatu ketinggian dengan wilayah data untuk Kota Mataram yang didapat dari survei sekunder ke instansi Badan Informasi Geospasial (BIG). Selain itu, penelitian ini juga menggunakan data pasang surut air laut untuk silayah perairan Selat Lombok yang didapat melalui survei sekunder pada buku pasang surut perairan Indonesia 2016 yang didapat dari instansi BAKOSURTANAL.

\section{B. Identifikasi Luasan Wilayah Eksisting Terdampak Banjir Akibat Gelombang Pasang}

Tahapan awal yang dilakukan ialah proses pengolahan data spot height menggunakan metode interpolasi kriging. Metode kriging dipilih karena memiliki nilai tingkat error yang paling rendah dibanding metode interpolasi lainnya. Hasil dari metode interpolasi kriging ialah berupa peta DEM (Digital Elevation Model).Selanjutnya hasil DEM tersebut diubah ke dalam bentuk raster untuk selanjutnya akan digunakan sebagai input analisis raster calculator.

Selanjutnya dilakukan penentuan pasang tertinggi dalam data tahun terakhir, yakni data pasang surut Tahun 2016. Setelah pasang tertinggi sudah ditentukan, maka barulah bisa dijalankan analisis raster calculator. Tampilan interface raster calculator seperti gambar di bawah ini :

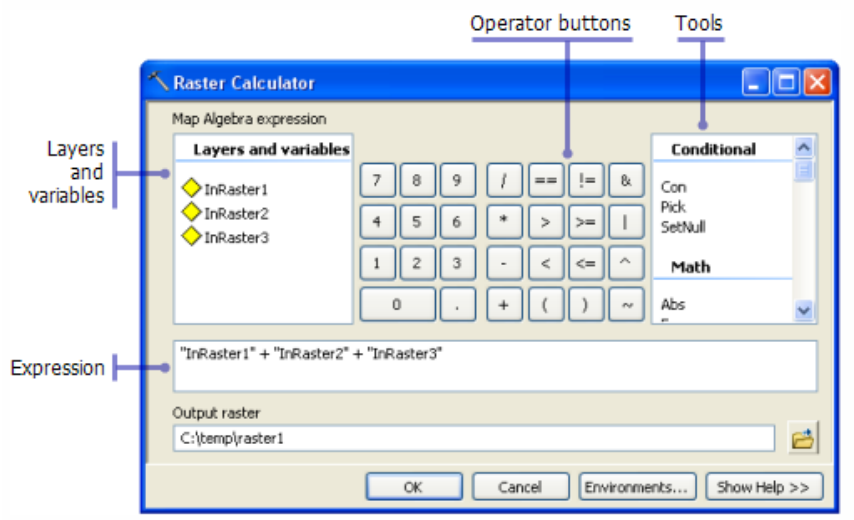

Gambar 1. Ilustrasi Raster Calculator

Selanjutnya, masukkan formula yang terdiri dari data interpolasi berupa DEM serta pasang tertinggi. Berikut ialah formula yang digunakan :

BanjirEksisting $=\mathrm{CON}([$ RasterDEM $]<=[$ PasangTertinggi $], 1,0)$
Angka "1" pada raster menunjukkan daerah tergenang, sedangkan angka " 0 " menunjukkan daerah yang tidak tergenang banjir.

\section{Membuat Pemodelan Genangan Banjir Pasang 2016- 2116}

Kenaikan muka air laut untuk Selat Lombok rata-rata $6 \mathrm{~mm} /$ tahun [8]. Untuk itu, digunakanlah rumus penentuan pasang tertinggi tahun prediksi dengan menggunakan persamaan yang diadaptasi dari [9]

$\mathrm{SLRp}=\mathrm{SLRr} *(\mathrm{Yp}-\mathrm{Yb})$

TLmax $=$ HHWL + SLRp

Keterangan :

SLRp : Sea level rise prediction; prediksi tinggi kenaikan muka air laut

SLRr : Sea level rise rates; tinggi kenaikan muka air laut per tahun

Yp : Year prediction; tahun prediksi

$\mathrm{Yb}$ : Year basis; tahun basis

TLmax : Tide level maximum; tinggi muka air pasang maksimum tahun prediksi

HHWL : Highest high water level; muka air tinggi tertinggi (air tertinggi pada saat pasang surut purnama atau bulan mati)

Selanjutnya, masukkan formula yang terdiri dari data interpolasi berupa DEM serta pasang tertinggi tahun prediksi. Berikut ialah formula yang digunakan :

BanjirTahunPrediksi $=\mathrm{CON}([$ RasterDEM $]<=[$ PasangTertinggi

TahunPrediksi],1,0)

Setelah itu klik "OK" maka raster luasan banjir pasang tahun prediksi akan muncul. Angka "1" pada raster menunjukkan daerah tergenang, sedangkan angka " 0 " menunjukkan daerah yang tidak tergenang banjir.

D. Identifikasi Luasan Penggunaan Lahan Terdampak Banjir di Wilayah Pesisir Kota Mataram 2016-2116

Untuk mengetahui penggunaan lahan apa saja yang terdampak banjir, dilakukan analisis overlay. Analisis overlay yang digunakan kali ini adalah analisis overlay jenis intersect. Overlay intersect ini diperlukan dalam penelitian ini untuk memperoleh dan menggabungkan informasi penggunaan lahan pada beberapa periode yang berbeda untuk kemudian dilakukan perbandingan dan interpretasi secara langsung maupun untuk mempermudah dalam melakukan penghitungan luas lahan yang terdampak genangan banjir akibat gelombang pasang.

\section{HASIL DAN DISKUSI}

A. Identifikasi Luasan Wilayah Eksisting Terdampak Banjir Akibat Gelombang Pasang

Berikut ialah hasil interpolasi kriging dari data spot heigt wilayah Kota Mataram : 


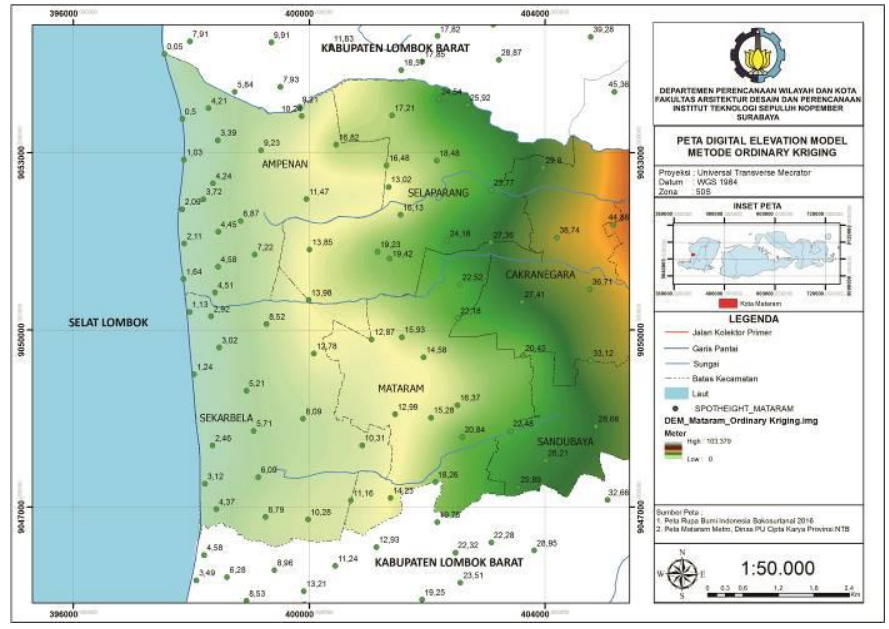

Gambar 2. DEM Interpolasi Kriging

Adapun ketinggian pasang surut tertinggi tahun 2016 ialah setinggi 2,00 meter. Dengan kata lain, ketinggian banjir yang menggenangi wilayah pesisir Kota Mataram ialah wilayah dengan ketinggian 0-2 meter. Setelah itu, dilakukan analisis raster calculator dengan ketinggian banjir 2 meter, maka didapati luasan wilayah yang tergenang sebagai berikut :

Tabel 1.

Luasan Banjir Tahun 2016 Per Kelurahan

\begin{tabular}{llc}
\hline \hline Kecamatan & Kelurahan & Luas Banjir (Ha) \\
\hline Ampenan & Banjar & 1,5045 \\
& Bintaro & 35,7923 \\
& Ampenan Selatan & 7,2231 \\
& Ampenan Tengah & 3,3886 \\
Sekarbela & Jempong Baru & 4,2405 \\
& Tanjung Karang Permai & 17,793 \\
& Tanjung Karang & 32,924 \\
Total & & 102,866 \\
\hline \hline
\end{tabular}

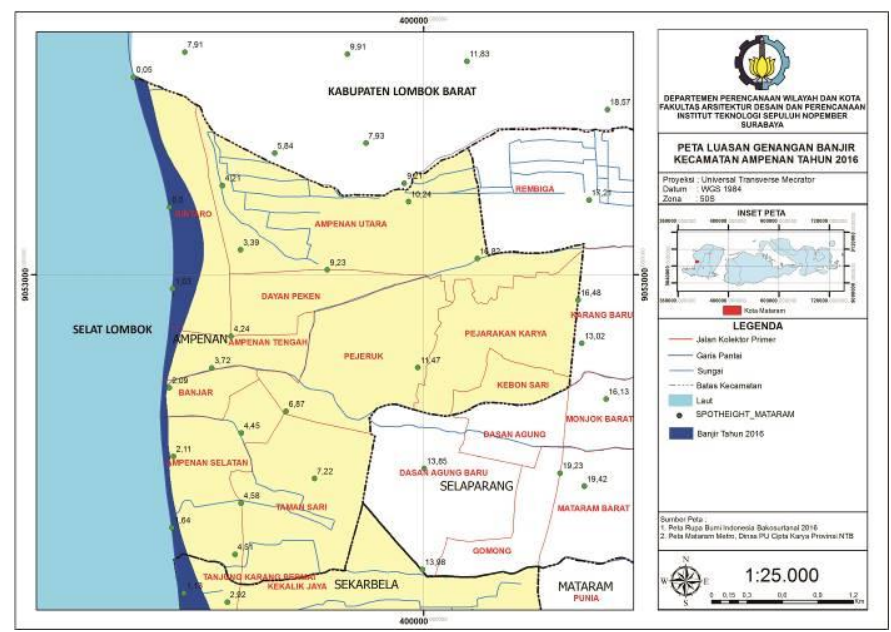

Gambar 3. Luasan Banjir Tahun 2016 Kecamatan Ampenan

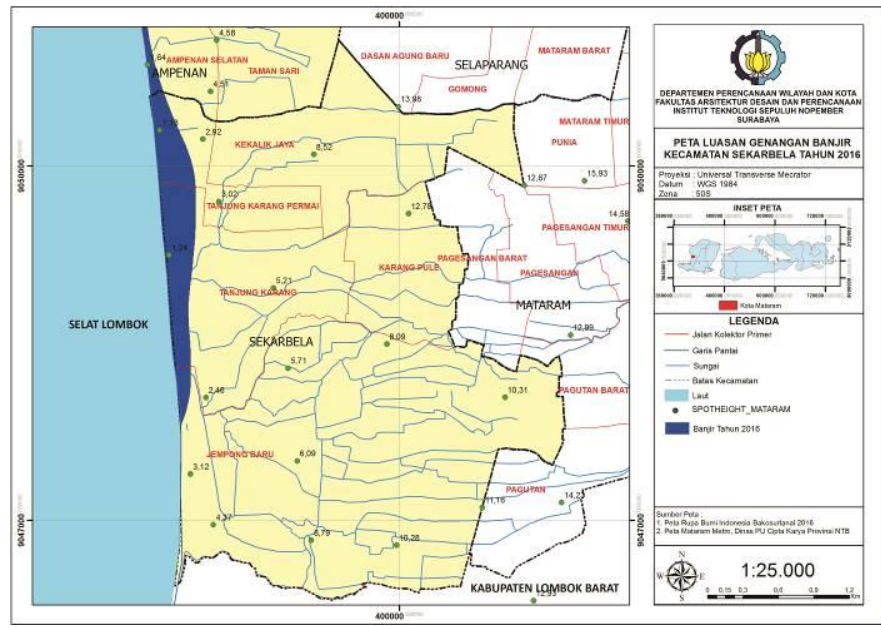

Gambar 4. Luasan Banjir Tahun 2016 Kecamatan Sekarbela

\section{B. Pemodelan Genangan Banjir Pasang Tahun 2016-2116}

Dengan diketahui bahwa tinggi muka air laut (HHWL) tahun 2016 setinggi 2,00 meter. Berdasarkan penelitian yang dilakukan [8] menyebutkan bahwa data kenaikan muka air laut Selat Lombok ialah sebesar $6 \mathrm{~mm} /$ tahun. Maka formula yang digunakan ialah sebagai berikut :

$$
\begin{aligned}
& \text { SLR2066 }=6 \mathrm{~mm} *(2066-2016) \\
& \quad=6 \mathrm{~mm} * 50 \\
& =300 \mathrm{~mm}(0,3 \text { meter }) \\
& \text { TL2066 }=2,00+0,3 \\
& \quad=2,30 \text { meter } \\
& \text { SLR2 } 116=6 \mathrm{~mm} *(2116-2016) \\
& \quad=6 \mathrm{~mm} * 100 \\
& =600 \mathrm{~mm}(0,6 \text { meter }) \\
& \text { TL2066 }=2,00+0,6 \\
& =2,60 \text { meter }
\end{aligned}
$$

Setelah dilakukan perhitungan, maka ketinggian muka air laut untuk tahun 2066 ialah setinggi 2,3 meter dan ketinggian muka air laut untuk tahun 2116 ialah setinggi 2,6 meter. selanjutnya ialah menjalankan analisis raster calculator dengan formula sebagai berikut :

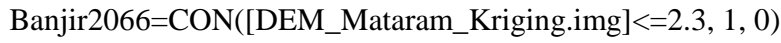

Banjir2116=CON([DEM_Mataram_Kriging.img $]<=2.6,1,0)$

Setelah dilakukan analisis raster calculator didapati bahwa luasan banjir yang terjadi di Kecamatan Ampenan dan Kecamatan Sekarbela tahun 2016, 2066 dan 2116 ialah sebagai berikut :

Tabel 2.

Luasan Banjir Tahun 2016, 2066 dan 2116 Per Kelurahan

\begin{tabular}{lllll}
\hline \hline Kecamatan & Kelurahan & $\begin{array}{c}\text { Luas } \\
\text { Banjir } \\
2016(\mathrm{Ha})\end{array}$ & $\begin{array}{c}\text { Luas } \\
\text { Banjir }\end{array}$ & $\begin{array}{c}\text { Luas } \\
\text { Banjir } \\
2116 \\
\text { (ha) }\end{array}$ \\
\hline \multirow{5}{*}{ Ampenan } & Banjar & 1,5045 & 3,5238 & 5,6261 \\
& Bintaro & 35,7923 & 46,0313 & 56,2988 \\
& Ampenan & 7,2231 & 14,0421 & 20,8605 \\
& $\begin{array}{l}\text { Selatan } \\
\text { Ampenan }\end{array}$ & 3,3886 & 6,0062 & 8,4498 \\
& Tengah & 4,2405 & 8,5729 & 11,6570 \\
\hline \hline
\end{tabular}




\begin{tabular}{lllll}
\hline \hline & Tanjung Karang & 17,793 & 22,0713 & 27,4643 \\
& Permai & & 45,5162 & 57,4309 \\
& Tanjung Karang & 32,924 & 4 & 0,0613 \\
& Kekalik Jaya & - & - & 187,849 \\
\hline Total & & 102,866 & 145,7638 & \\
\hline \hline
\end{tabular}

\begin{tabular}{lccc}
\hline \hline Hutan bakau & 2,739779 & 4,138384 & 4,394069 \\
Hutan Rawa & 1,687962 & 1,845646 & 1,950927 \\
Kawasan_Pertanian & 20,60718 & 34,46084 & 45,52131 \\
Lapangan & - & - & 0,158304 \\
Pasir pantai & 20,18487 & 21,17172 & 21,43614 \\
Pemakaman umum & 1,553205 & 3,192157 & 5,591685 \\
Pemukiman & 23,59923 & 37,17769 & 54,85012 \\
Perdagangan & - & - & 0,122822 \\
Semak Belukar & 0,354479 & 0,584942 & 1,025586 \\
Tanah kosong & 8,576719 & 12,40989 & 16,60838 \\
Total & 85,00659 & 121,3794 & 158,0574 \\
\hline \hline
\end{tabular}

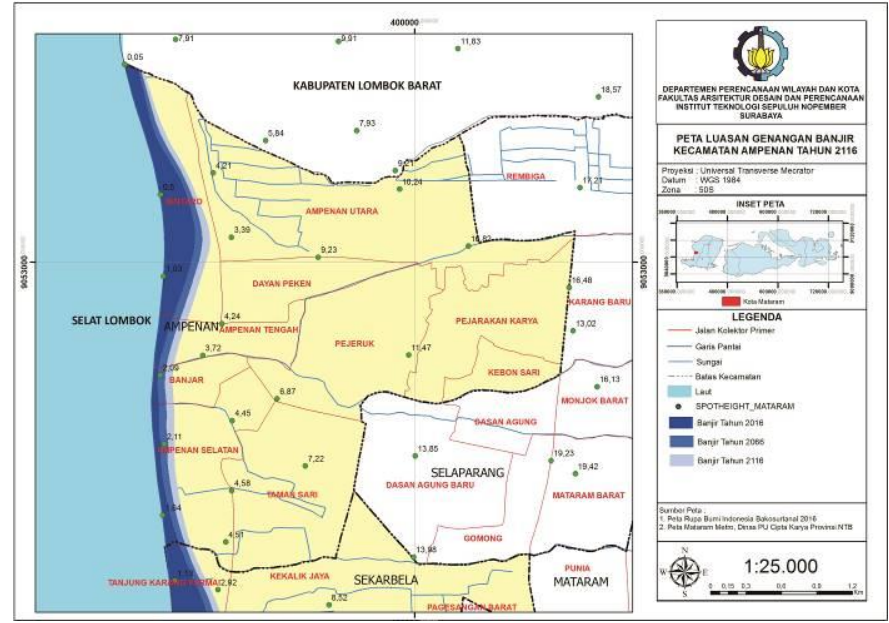

Gambar 5. Luasan Banjir Tahun 2016, 2066 dan 2116 Kecamatan Ampenan

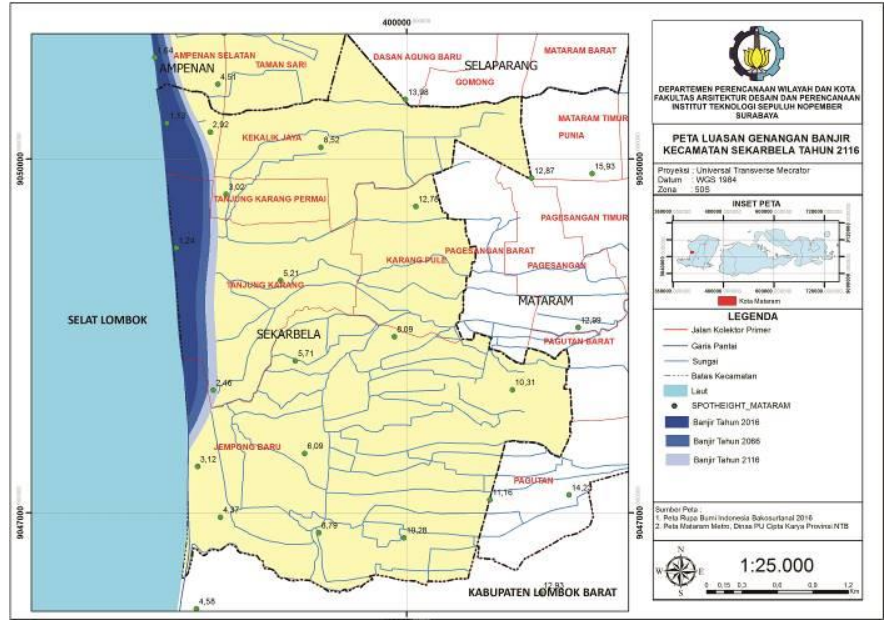

Gambar 6. Luasan Banjir Tahun 2016, 2066 dan 2116 Kecamatan Sekarbela

\section{Penggunaan Lahan Terdampak Banjir di Wilayah Pesisir Kota Mataram Tahun 2016-2116}

Berdasarkan hasil analisis overlay, pada tahun 2016 dan 2066, terdapat 9 jenis penggunaan lahan yang terendam banjir, diantaranya depo bahan bakar mini, hutan bakau, hutan rawa, kawasan pertanian, pasir pantai, pemakaman umum, permukiman, semak belukar, dan tanah kosong. Sedangkan tahun 2116 terjadi penambahan jenis penggunaan lahan yang terendam banjir, yakni lapangan dan perdagangan. Berikut ialah luasan penggunaan lahan yang terdampak banjir :

Tabel 3.

Luas Penggunaan Lahan Terdampak Banjir Tahun 2016, 2066 dan 2116

\begin{tabular}{crrr}
\hline \hline \multirow{2}{*}{ Penggunaan Lahan } & \multicolumn{3}{c}{ Tahun } \\
\cline { 2 - 4 } & 2016 & 2066 & 2116 \\
\hline Depo bahan bakar min & 5,703173 & 6,398093 & 6,398093 \\
\hline \hline
\end{tabular}

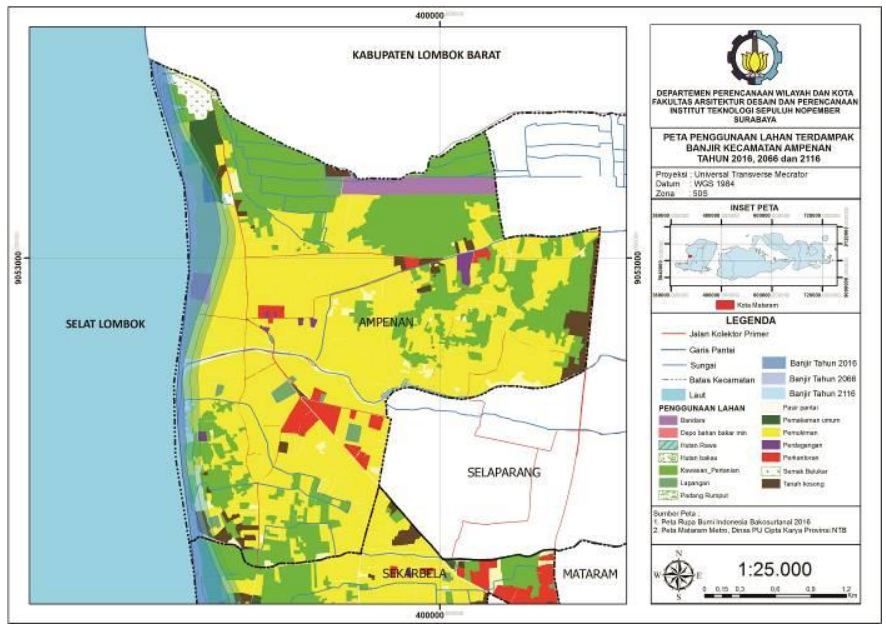

Gambar 7. Luas Penggunaan Lahan Terdampak Banjir Tahun 2016, 2066 dan 2116 Kecamatan Ampenan

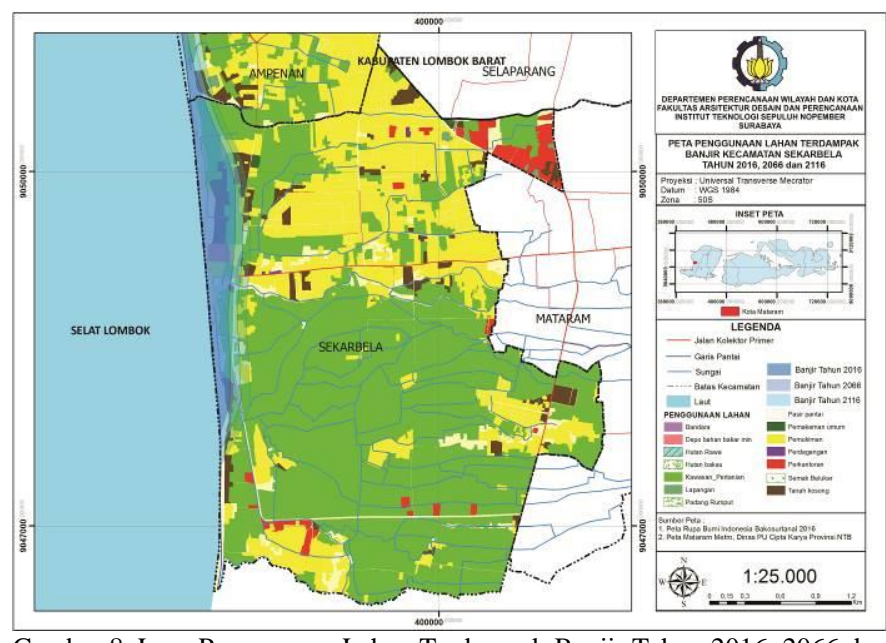

Gambar 8. Luas Penggunaan Lahan Terdampak Banjir Tahun 2016, 2066 dan 2116 Kecamatan Sekarbela

\section{KESIMPULAN}

Berdasarkan seluruh proses analisis yang telah dilakukan untuk menghasilkan pemodelan banjir akibat gelombang pasang di wilayah pesisir Kota Mataram, ada beberapa poin yang dapat disimpulkan sebagai berikut : 
1. Model yang terbentuk untuk menghasilkan proyeksi luasan banjir akibat gelombang pasang ialah

2. BanjirTahunPrediksi $=\mathrm{CON}([\mathrm{RasterDEM}]<=[\mathrm{HHWL}+\mathrm{SLR}]$, 1,0

3. Aspek yang paling berpengaruh dalam menentukan seberapa luas banjir ialah ketelitian dari data Digital Elevation Model.

4. Luasan wilayah banjir tahun 2016 seluas 102,866 ha, tahun 2066 seluas 145,7638 ha, dan tahun 2116 seluas 187,8490 ha. Wilayah yang tergenang sebagian besar berupa permukiman dan kawasan pertanian.

\section{DAFTAR PUSTAKA}

[1] D. Subiantoro, Global Warming For Beginner. Yogyakarta: Penembahan Yogyakarta, 2008.

[2] G. W. Anderson, "Implications of Global Climate Change in Alaska and the Bering Sea Regions," Univ. Alaska, 1998.

[3] IPCC, Guidelines for National Greehouse Gas Inventories. Washington D.C., 2006.

[4] I. Susandi, A., \& Herlianti, "Dampak Perubahan Iklim Terhadap Ketinggian Muka Air Laut di Wilayah Banjarmasin," Inst. Teknol. Bandung, 2008.

[5] M. P. Wilayah, "Tinjauan Aspek Penataan Ruang Dalam Pengelolaan Wilayah Laut dan Pesisir," in Seminar Umum Dies Natalies ITS Ke-43, 2003.

[6] T. K. Mataram, TAGANA Kota Mataram. Mataram, 2016.

[7] H. Supardi, "antara.news.com, Interviewer," 2016. [Online]. Available: antara.news.com, Interviewer.

[8] I. Sofian, I., \& Nahib, "Proyeksi Tinggi Kenaikan Muka Air Laut dengan Menggunakan Data Altimetri dan Model IPCC-AR4," Globë Vol., vol. 12, no. 2, pp. 173-181, 2010.

[9] N. A. Pratomoatmojo, "Landuse Change Modelling Under Tidal Flood Scenario by Means of Markov-Cellular Automata in Pekalongan Municipal," Univ. Gajah Mada, 2012. 